\title{
Lucien Bianco, La révolution fourvoyée: Parcours dans la Chine du XXe siècle (Revolution derailed: Journeys in twentieth century China)
}

La Tour d'Aigues, L'Aube, 2010, 230 pp.

André Laliberté

Translator. N. Jayaram

\section{(2) OpenEdition}

1 Journals

\section{Electronic version}

URL: http://journals.openedition.org/chinaperspectives/6056

DOI: 10.4000/chinaperspectives.6056

ISSN: 1996-4617

\section{Publisher}

Centre d'étude français sur la Chine contemporaine

\section{Printed version}

Date of publication: 7 December 2012

Number of pages: 74

ISSN: 2070-3449

\section{Electronic reference}

André Laliberté, "Lucien Bianco, La révolution fourvoyée: Parcours dans la Chine du xxe siècle (Revolution derailed: Journeys in twentieth century China) », China Perspectives [Online], 2012/4 | 2012, Online since 01 December 2012, connection on 23 September 2020. URL : http://journals.openedition.org/ chinaperspectives/6056 ; DOI : https://doi.org/10.4000/chinaperspectives.6056

This text was automatically generated on 23 September 2020

(c) All rights reserved 


\section{Lucien Bianco, La révolution} fourvoyée: Parcours dans la Chine du $\mathrm{XX}^{e}$ siècle (Revolution derailed: Journeys in twentieth century

\section{China)}

La Tour d'Aigues, L'Aube, 2010, 230 pp.

André Laliberté

Translation : N. Jayaram 
1 This anthology introduced by Michel Bonnin and prefaced by Marie-Claire Bergère exemplifies the career of an iconoclastic thinker whose ideas met with indifference from the public at large and much scepticism on the part of the Maoist regime's admirers in the 1960s but who has since been proved right. The historian's ten essays in this collection have lost none of their relevance, even the oldest of them, "La page blanche" (The blank page). Written during the Cultural Revolution, when few sources were available, it challenged the benign image of the Maoist regime that many Western fellow-travellers peddled. Bianco did not shirk from denouncing the "disaster" that was the "Great Leap Forward," even though data on this catastrophic policy were as yet largely lacking. He arrived at

Lucien Bianco

La révolution fourvoyée Parcours dans la Chine du $x x^{\circ}$ siècle

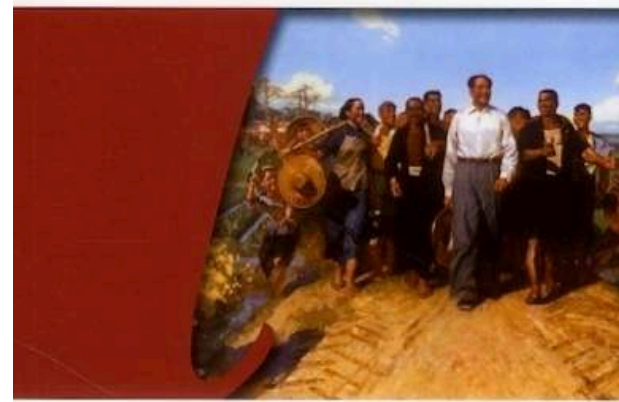
this judgement on the basis of deep study and rigorous analysis of available sources, and moreover correctly identified the causal chain from the Great Leap famine to the Cultural Revolution.

2 Although primarily known as a historian of pre-1949 Chinese peasantry - his "Les origines de la révolution chinoise" won him notice - Lucien Bianco was among the first to render judgment on Mao and Maoism by making comparisons between the Soviet regime and the famous "Chinese road to socialism." In his view, Maoism differed from the Soviet model only in its details, and Stalinism had much greater influence on prereform China than was admitted in the 1970s. In "La révolution fourvoyée" (The derailed revolution), published after Mao's death, and which is also this anthology's title, he concluded that in his last 20 years, Mao divested the revolution of its raison d'être, i.e., development. In "Essai de définition du maoïsme" (Defining Maoism), written in 1979, Bianco displayed sagacity by lamenting the extent to which Mao Zedong Thought in the post-Mao era had not ended the exploitation of the majority of the population, but rather had served the ends of a new power in the world stage.

Demographic issues are among the other topics Bianco deals with. In "La population chinoise face à la règle de l'enfant unique" (The Chinese population and the one-child policy), he becomes a historian of contemporary China and narrates the horrors inflicted by that policy in the 1980s, but also shows himself a pioneer in pointing out the consequences of this policy in terms of population aging and gender imbalance, two problems now attracting increasing attention. Although China's future is increasingly in urbanites' hands, the difficulties farmers face remain the major worry. Bianco's most recent output on the peasantry is likely to continue inspiring scholarship on rural issues today: "Conflits villageois dans la Chine $\mathrm{du} \mathrm{xx}^{\mathrm{e}}$ siècle" (Village conflicts in twentieth century China) examines the problem of xiedou, conflicts between clans and villages that the regime has failed to quell. In "Vingt-cinq ans de réformes rurales, 
après le beau temps, la pluie" (Twenty-five years of rural reforms: After fair weather the storm), he paints an unflattering picture of agriculture reforms, which stumbled after the initial advances of the 1980s. The strength of Bianco's historical analyses lies in his highlighting of basic differences between peasant unrest in Republican China and after 1949. In a short essay, "L'agitation paysanne menace-t-elle le régime?" (Does peasant unrest threaten the regime?), written in the wake of riots in a Sichuan village in 1993, he argued that such incidents should not be seen as harbingers of the regime's collapse: whereas the Communist Party could channel peasant grievances against the regime before 1949, no such route exists now. On the whole, these essays testify to the integrity of Bianco's approach and his critical posture irrespective of changes in the regime's leadership. At a time when China's successful economic development is being bandied about, as Bianco has noted in his most recent essay in this collection, "Mao et son modèle" (Mao and his model), it is refreshing that he has not been taken in by the widespread enthusiasm for the "authoritarian advantage" thesis. This owes to a constant theme in his works, a never-yielding stand in support of the Chinese peasantry.

4 Finally, two revealing texts describe a period some people wish to forget, when the regime clumsily sought to convince "foreign friends" of the correctness of the policies of the day. In "Comment Yugong déplaça les montagnes" (How Yugong moved mountains), published at the end of the Cultural Revolution, Bianco bitingly ridicules a series of documentary films by fellow-travellers deluded by the Chinese regime. "Voyage en Chine" (China travels), also written in 1970, describes with a dash of humour the subterfuges and manipulations Chinese authorities employed in persuading "foreign friends" to "correctly" describe New China's realities. Obviously, and this shines through in every page of this remarkable collection of essays, Bianco writes as a sincere friend of China without ever bowing to Party diktat. This excellent collection not only throws useful light on important themes in China's recent history, but also stands out as an example of the rigour to be observed in social sciences. Political scientists, sociologists, and anthropologists will appreciate Bianco's interpretative work, which makes judicious use of historic materials.

\section{AUTHORS}

\section{ANDRÉ LALIBERTÉ}

Professor at the School of Political Studies, University of Ottawa. 